During the Oxford period he wrote his "Introduction to Social Psychology", "Body and Mind", "The Pagan Tribes of Borneo" (with Dr. Charles Hose), the small Home University text-book and finally "The Group Mind". The first of these books, he says, dropped like "a stone into a bottomless pit". If so, it has successfully bounced out again, exhausted some twenty-three large editions and vastly influenced very nearly everything that psychologists have written about the subject since.

After the War, McDougall was invited to succeed. Münsterberg in the chair of psychology at Harvard. He went to the United States with high hopes, found there very many friends, but was plunged into intense public controversy which persisted to the end of his life. American behaviourism represented for him everything which he most heartily disliked. He attacked it vigorously. He continued his attacks long after the battle had, to all intents, been won. He published book after book, and the motive of them all was the same, to fight all types of 'mechanistic' explanation in every field of science and to do this in the interests of "the art and theory of the internal life of man".

Harvard did not hold him for long. In 1927, he accepted a new chair of psychology at Duke University, North Carolina, and there he remained, latterly with yearly visits to England, until his death. On the whole this suited him the best of all his many dwelling-places. The less hurried, more patriarchal atmosphere fitted well with his temperament and helped his work. His philosophical and ethical interests, always strong, became ever more pronounced. As a psychologist his primary concern was to establish a wide teleological point of view, and in so far as his experimental interests persisted, they were confined to a general approval of work on telepathy, clairvoyance and the like, and to his well-known Lamarckian experiment.

McDougall began the Lamarckian work at Harvard and continued it at Duke. He considered the question at issue "the most important question yet formulated by the mind of man and clearly susceptible of solution by experimental procedure"; and he was firmly convinced that his own long-continued work with white rats had achieved a "clear-cut and indisputable proof of the reality of Lamarckian transmission".

A few months before his death McDougall published his last book, "The Riddle of Life". He had set out, an unwearied soldier, upon his old campaign against mechanistic explanation in Nature and in life. He had conducted it with brilliance and with vigour. He was in the grip of a painful and a fatal disease. Only a "marvellous operation" enabled him to complete the work. As he read the proofs of this book it seemed to him that possibly some of his criticisms of physical and biological men of science might appear to be harsh and unsympathetic. So, himself near to death, he paid a last tribute to scientific endeavour. "I am now more than ever sensible of the splendour and achievements of modern science, and grateful to those whose skill and labour and genius have made possible such great benefits as I have received from the hands of my colleagues". He desired only that science should discard all pontifical claims and remain humble and honest in its search for truth. For himself the beginnings of the ultimate truth had been found. He saw in all forms of behaviour "some large unity or community of Nature underlying the separate individual organisms". He believed that, within every society, from insects to man, he could discern a harmony of activities "secured by the direction of some intelligent purpose more comprehensive and powerful than that of any individual member".

F. C. Bartumit.

AN anthropological correspondent writes :

Prof. McDougall, with the late Dr, W. H. R. Rivers, was a pioneer in the application of the methods of scientific psychology to the study of peoples of backward culture in the field, when they were both members of the Cambridge Anthropological Expedition to the Torres Straits under the leadership of Dr. A. C. Haddon. One outcome of this early interest in primitive mentality was "The Pagan Tribes of Borneo", which Prof. MeDougall published in 1912 in collaboration with the late Dr. (afterwards Sir) Charles Hose. This intimate and detailed study of peoples, who when first known to one of the authors were in the enjoyment of a simple culture barely touched by European influence, is still one of the most highly regarded of ethnological treatises belonging to the early part of this century. A further result of Prof. McDougall's early studies in social anthropology is to be seen in his bent towards the sociological implications of psychological studies, which is apparent throughout his published works, and is especially to be noted in the analyses of world problems, which he has produced in the years since the Great War.

\section{Prof. Georges Urbain}

THE death on November 5 of Prof. Georges Urbain, director of the Institut de Chimie, past-president of the French Chemical Society, removes a well-known figure from French scientific life.

Borm in Paris on April 12, 1872, son of a professor of chemistry, he studied at the Paris School of Physics and Chemistry and carried out research work under Friedel, Schutzenberger and Jean Perrin, obtaining his doctor's degree for investigations on the rare earths.

After five years of industrial research with the Compagnie générale d'Électricité, Urbain returned to academic life, lecturing at the School of Physics and Chemistry and later at the Faculty of Sciences of the Sorbonne, where he became professor in 1908.

The name of Urbain will always be associated with our knowledge of the rare earths. He showed that a number of so-called pure elements belonging to that series were in fact mixtures of europium, gadolinium, terbium and dysprosium. On the other hand, from ytterbium he separated a new element, lutecium (atomic number 71) and forecast the existence of a further element of atomic number 72 (celtium) which was later identified by Hevesy (haforium.) 
In pursuing the difficult investigations connected with the separation of the rare earth elements, Urbain showed great versatility in employing many physical and chemical methods, often necessitating prolonged and tedious work. It is estimated that, together with Lacombe, he had carried out some 200,000 fractional crystallizations over a period of fifteen years.

Like preceding investigators, Urbain began by studying the absorption and emission spectra of the rare earths, then went on to the magnetic properties and the phosphorescence in cathode tubes, discovering the law of optimum phosphorescence of binary systems. He also carried out many accurate atomic weight determinations.

In addition to his work on the rare earths, Urbain will be remembered for his contribution to the study of complex inorganic salts, which he considered to form a link between inorganic and organic compounds.

During his career, Urbain filled many important posts. He lectured at the Ecole Centrale and presided over the Experimental Section of the Ecole des Hautes Etudes. In the Great War he directed the Chemical and Technical Section of the Artillery.

These numerous activities none the less left Urbain time for artistic recreations. Those who attended the banquet in his honour given at the Maison de la Chimie last June were privileged to hear several of his original musical productions.

WE regret to announce the following deaths :

Prof. Edwin H. Hall, emeritus professor of physics in Harvard University, on November 20, aged eightythree years.

Prof. J. Šplíchal, professor of inorganic and analytical chemistry in the School of Mines, Př́bram, Czechoslovakia, who had only recently completed a lengthy study of the thermal decomposition of the carbonates of calcium, magnesium, iron and manganese, on December 8, aged fifty-three years.

\section{New s and Views}

\section{Society for the Protection of Science and Learning}

Perhaps there is no finer testimony to the work undertaken by the Society for the Protection of Science and Learning, the report for 1938 of which was referred to in NATURE of December 17 (p. 1051) than the extent to which it has received the active support during the whole of its five years existence of the university staffs in Great Britain. Not only have individuals and committees in the majority of academic centres lent ready assistance to their exiled colleagues from abroad in the way of advice and vigilance for new openings for them, but also they have contributed financially more than $£ 10,000$ towards the funds of the organization which seeks to aid academic refugees. The Society itself has arranged a week of meetings early next term to take place in the great majority of British academic centres, with the view of spreading information concerning the plight and prospects of academic refugees. Among those who have agreed to take part in these meetings are included: the Home Secretary, the Archbishop of York, Viscount Samuel, the Marquess of Reading, Sir William Bragg, Sir Henry Dale, Sir Richard Gregory, Sir John Hope Simpson, Sir Norman Angell, Sir Allen Mawer, Sir Bernard Pares, the Hon. Harold Nicolson, Mr. Philip Guedalla, Mr. Walter Adams, Prof. Gilbert Murray, Prof. Winifred Cullis, Prof. John Macmurray, Prof. P. M. S. Blackett, Prof. Lancelot Hogben, Prof. F. A. E. Crew, Miss Rebecca West and the Hon. V. Sackville-West. The Royal Society is giving a special reception to the academic exiles and those who have been working in their interests, in collaboration with the British Academy, on February 7 ; and on February 10 the evening discourse at the Royal Institution is to be given by Prof. Max Born, one of the most distinguished of the refugee men of science.

\section{The Chemical Society}

Ar a meeting of the Chemical Society held at the Royal Institution on December 15, it was stated that Prof. Robert Robinson, Waynflete professor of chemistry in the University of Oxford, has accepted nomination to the office of president for the period 1939-41, which includes the centenary celebrations of the Society to be held in April 1941. The Long. staff Medal for 1939 has been awarded to Prof. I. M. Heilbron, for his outstanding contributions to the science of chemistry in the field of natural products, especially vitamin A and related natural pigments, the anti-rachitic vitamin $\mathrm{D}$ and its precursors, and the constituents of the fish liver oils and of natural resins of the triterpene group. Prof. Heilbron was lecturer in organic chemistry in the Royal Technical College, Glasgow, from 1909 until 1914, and in 1919 became professor of organic chemistry there. In 1920 , he proceeded to the University of Iiverpool as professor of organic chemistry; in 1933 he held the chair of organic chemistry in the University of Manchester. In 1938, he was appointed professor of organic chemistry at Imperial College, London.

Ar the meeting of the Harrison Memorial Prize Selection Committee, consisting of the presidents of the Chemical Society, the Institute of Chemistry, the Society of Chemical Industry, and the Pharmaceutical Society, held on December 14, it was decided that the Harrison Memorial Prize for 1938 should be awarded to Mr. Alexander King. Mr. King received his chemical training at the Imperial College, South Kensington. From 1930 until 1931, he worked in the Physical Chemistry Institute of the University of Munich under Prof. K. Fajans, and from 1931 to the present date has held the post of assistant 